\title{
INFORMAÇÃO ECONÓMICA E ESTRATÉGIA DAS EMPRESAS
}

\author{
IVA M. PIRES ${ }^{1}$
}

\begin{abstract}
A informação económica (intelligence économique), tema abordado neste livro $^{2}$, pode definir-se como «o conjunto de acções coordenadas de investigação, tratamento e distribuição com vista à sua utilização, de informação útil aos actores económicos» (p.16) e distingue-se das acções clássicas de documentação pois neste caso a procura e gestão da informação faz parte de uma intenção táctica que a orienta. Incluem-se neste caso a procura sistemática de informações com o objectivo de munir a empresa (os diferentes níveis de decisão da empresas ou da colectividade) de um instrumento de trabalho que lhe permita, por exemplo, antecipar as alterações de mercado, conhecer a evolução da concorrência, detectar e avaliar ameaças e oportunidades. A gestão dessa informação permitirá à empresa (o mesmo acontecerá no caso de um país, de uma região ou de uma cidade) delinear as estratégias de desenvolvimento (ofensivas ou defensivas) mais adequadadas à conjuntura económica mundial ou ao mercado específico no qual se insere. A capacidade para obter, tratar e usar informação estratégica em proveito próprio distinguirá, assim, as empresas com maior ou menor performance e, ao mesmo tempo, a sua competitividade num mercado global fortemente concorrencial. No entanto, isso implica normalmente custos elevados pela necessidade de afectar pessoal qualificado exclusivamente a essa função, que deve definir o tipo de informação a ter em conta, a abrangência geográfica e sectorial da observação, a escolha dos utensílios e fontes de informação, o que só se justifica no caso de empresas transnacionais de grande dimensão ${ }^{3}$. Talvez por isso os sectores percursores na utilização da intelligence économique tenham sido o petrolífero e o da defesa e produção de armamento.

Mas, como referem os autores do grupo de trabalho presidido por H. Martre,
\end{abstract} na actual conjuntura de pressão concorrencial provocada pela mundialização das trocas, pela renovação dos comportamentos (dos actores económicos e dos consumidores), pela complexificação das relações entre empresas e em que os factores imateriais de competitividade são fundamentais, a informação assume um papel fundamental no desenvolvimento de qualquer empresa ou no fortaleciemnto dos tecidos económicos locais. Do mesmo modo, a necessidade de defender sectores estratégicos e de os apoiar na luta por uma fatia do mercado internacional conduz os Estados a criar verdadeiros «sistemas de informação económica» ${ }^{4}$. Daí a importância em se abordar este tema.

No primeiro capítulo são analisados e comparados os «sistemas de informação económica» pioneiros, como o inglês e o sueco, e os que actualmente estão mais desenvolvidos - o japonês, o norte-americano e o alemão. Eles divergem na sua con-

\footnotetext{
${ }^{1}$ Professora Auxiliar, Departamento de Sociologia, UNL. Colaboradora do Centro de Estudos Geográficos.

2 Henri Martre (ed.) (1994), Intelligence Économique et Stratégie des Entreprises, La Documentation Française.

${ }^{3}$ Um dos exemplos dados é o da cadeia de hotéis Marriott que, em 1988, decidiu observar discretamente os principais concorrentes. Empregados seus transformaram-se em clientes com o objectivo de testar a qualidade, o atendimento, bem como a reacção a pequenos incidentes provocados na instalação eléctrica, nos telefones, ou a doença súbita, etc (p.58).

${ }^{4}$ Por «sistemas de informação económica» entende-se «o conjunto de práticas e de estratégias de utilização de informação útil, desenvolvidos num país nos seus diferentes níveis de organização: o do Estado, do governo, da indústria, das empresas, da educação e mesmo da população.» (p.27)
} 
cepção, objectivos e estrutura, em grande parte porque surgem em sociedades culturalmente distintas. Assim, enquanto o alemão é centralizado (os fluxos de informação convergem e são geridos por um núcleo central que inclui as grandes empresas, a Banca e as companhias de seguros) e orienta-se numa perspectiva de interesse nacional apoiando as empresas alemãs no exterior, o sistema americano, apesar de forte e complexo, é muito individualizado, cada empresa cria o seu e os objectivos são a obtenção de lucro a curto prazo ou a luta pela melhoria da posição da empresa no mercado nacional ou mundial. Por outro lado, enquanto o inglês teve a sua origem na necessidade de criar uma rede de informação que facilitasse a difusão das suas manufacturas no mercado mundial (da qual mais tarde beneficiaram as empresas petrolíferas inglesas), a elite japonesa da era Meiji usou a informação económica primeiro numa perspectiva defensiva (na tentativa de preservar a independência económica face às potências comerciais da época) e, posteriormente, numa perspectiva ofensiva para lançar as bases da industrialização do país.

No segundo capítulo é apresentado o sistema de informação francês, os seus principais intervenientes (empresas, Banca e Estado), os maiores desafios e lacunas e na conclusão propostas para o seu desenvolvimento.

Nos anexos, que representam um quarto do livro, é-nos fornecida, entre outra, informação sobre a China, a Rússia, a Itália e as dificuldades sentidas na elaboração de um sistema de informação que permita evitar burlas na cobrança do IVA no mercado da União Europeia. 